\title{
Chemical and microbiological changes and aerobic stability of marandu grass silages after silo opening ${ }^{1}$
}

\author{
Thiago Fernandes Bernardes ${ }^{2 *}$, Ricardo Andrade Reis ${ }^{3}$, Rafael Camargo do Amaral ${ }^{4}$ \\ 1 Pesquisa financiada pela Fundação de Amparo à Pesquisa do Estado de São Paulo. \\ 2 Pós-doutoramento - USP/ESALQ. Bolsista FAPESP. \\ ${ }^{3}$ Universidade Estadual Paulista - FCAVIUNESP. \\ 4 Programa de Pós-graduação em Ciência Animal e Pastagens - USP/ESALQ.
}

ABSTRACT - This trial had the objective of characterizing the microbial population and evaluating the aerobic stability of Marandu grass silages with pelleted citrus pulp (PCP). The collected forage was submitted to the following treatments: Silage of Marandu grass; silage of Marandu grass $+50 \mathrm{~g} / \mathrm{kg}$ PCP and silage of Marandu grass $+100 \mathrm{~g} / \mathrm{kg}$ PCP on natural matter basis. Metal cylindrical containers with $80 \mathrm{~cm}$ of height and $50 \mathrm{~cm}$ of diameter were used as silos during assays of microbiological dynamics and chemical changes of silages in anaerobiosis. Evaluations were performed on days 0, 2, 4 and 6 after silos were opened. The aerobic stability was evaluated by change in temperature, using approximately three kilograms of silage inside styrofoam boxes that were placed inside a climatic chamber. A completely randomized experimental design and split plot arrangement were used in the two assays, with five replications. Treatments were the plots and time was the subplots. Bacillus and enterobacteria were present on the Marandu grass silages with $0 \mathrm{~g} / \mathrm{kg}$ PCP, which also showed $\mathrm{pH}$ increase throughout the feedout phase. Yeast was detected on the silages that were added with PCP. A trend of increasing temperature with extension of the aeration time was observed mainly in the silages containing $100 \mathrm{~g} / \mathrm{kg}$ PCP. Isolated yeast strains showed lactate assimilation. Silages were found to be unstable due to the silo opening, both by bacterial or yeast development, which reduced the nutritional value.

Key Words: additive, Brachiaria brizantha, losses, spoilage microorganisms

\section{Alterações químicas e microbiológicas de silagens de capim-marandu após a abertura dos silos}

\begin{abstract}
RESUMO - Esta pesquisa foi realizada com os objetivos de caracterizar a microbiologia e avaliar a estabilidade aeróbia de silagens de capim-marandu contendo polpa cítrica peletizada (PCP). A forragem colhida foi submetida aos seguintes tratamentos: silagem de capim-marandu; silagem de capim-marandu $+5 \%$ PCP e silagem do capim-marandu $+10 \%$ de PCP com base na matéria natural. As alterações químicas e microbiológicas foram feitas aos 0, 2, 4 e 6 dias após a abertura dos silos (tambores de metal com $80 \mathrm{~cm}$ de altura e $50 \mathrm{~cm}$ de diâmetro). Na avaliação da estabilidade aeróbia por meio da alteração da temperatura, $3 \mathrm{~kg}$ de silagem foram colocados em caixas de isopor, que foram armazenadas em câmara climática. Nos dois ensaios realizados, utilizou-se delineamento inteiramente ao acaso com cinco repetições, em esquema de parcelas subdivididas, de modo que os níveis de PCP na silagem corresponderam às parcelas e o tempo, às subparcelas. As silagens sem polpa apresentaram desenvolvimento de bacilos e enterobactérias e aumento do $\mathrm{pH}$ no decorrer do desabastecimento dos silos. A presença de leveduras foi detectada nas silagens contendo o aditivo e aumentou do primeiro ao sexto dia de aeração. A digestibilidade in vitro da matéria seca (DIVMS) reduziu com o aumento dos tempos de aeração. A temperatura nas silagens com 10\% de PCP aumentou durante a aerobiose. Com a abertura dos silos, as silagens apresentaram-se instáveis, seja pelo desenvolvimento de bactérias seja pelo desenvolvimento de leveduras, o que reduziu seu valor nutritivo.
\end{abstract}

Palavras-chave: aditivo, Brachiaria brizantha, microrganismos espoliadores, perdas

\section{Introduction}

The anaerobic environment of a silo responsible for forage conservation becomes aerobic when the silo is opened. In such conditions, organisms that are latent in the absence of oxygen multiply rapidly, and silage is thus degraded. This phenomenon is evidenced by the development of undesirable microorganisms (bacteria and molds),

Received Mach 3, 2008 and accepted June 26, 2008

Corresponding author:tfbernardes@yahoo.com

* Current address: Departamento de Zootecnia - Instituto da Saúde e Produção Animal - Universidade Federal Rural da Amazônia, Belém - PA. 
increase in temperature and decrease in feed carbohydrate levels (Pahlow et al., 2003).

During ensilage of tropical grasses, the use of fermentation stimulating agents, such as citrus pulp, has led to the occurrence of yeast and filamentous fungi. Some well-fermented silages with additives and presenting high lactic acid levels and remaining sugars seem to be subject to fast deterioration by these microorganisms. The reason for such instability in silage supplemented with additives is probably related to the greater contents of energy sources for microorganisms involved in aerobic degradation (Kung et al., 2003).

During fermentation, the degradation of structural and non-structural carbohydrates and the factors affecting the availability of these fractions for microorganism metabolism must be considered. The fate of pectin differs from that of other non-structural carbohydrates during ensilage. The major part of sugars originated from non-structural carbohydrates are fermented when ensiled. Nevertheless, approximately $90 \%$ of the pectic uronic acids were not fermented in alfalfa silage studies after 90 days (BenGhedalia et al., 1991). According to Blanco et al. (1999), some yeast synthesize the enzyme polygalacturonase and are able to hydrolyze pectic substances using products as carbon source in the metabolism.

The objective of this work was to characterize the microorganism population and evaluate the aerobic stability of Marandu grass ensiled with pelleted citrus pulp as fermentation stimulating agent.

\section{Material and Methods}

The experiment was conducted at the FCAV/UNESP facilities, located at Jaboticabal, state of São Paulo, Brazil $\left(21^{\circ} 15^{\prime} 22^{\prime \prime} \mathrm{S}\right.$ and $\left.48^{\circ} 18^{\prime} 58^{\prime \prime} \mathrm{W}\right)$, with an altitude of $595 \mathrm{~m}$. The climate is Cwa - humid subtropical with dry winter through the international Koppen's system. Average maximum and minimum temperatures are $22.3^{\circ} \mathrm{C}$ and $15.17^{\circ} \mathrm{C}$. The average precipitation is approximately $1,400 \mathrm{~mm}$, and $85 \%$ of the rain is concentrated from October until March.

The soil was fertilized with nitrogen-based fertilizer in order to obtain adequate yield of pasture to be ensiled. Therefore, $65 \mathrm{~kg}$ N/ha was applied during November 2001, just after the matched cut of the forage.

The grass was harvested on January $17^{\text {th }}$, 2002, with 55 days of vegetative growth and chopped with a conventional forage harvester to a $3 \mathrm{~cm}$ theoretical length of cut.
The harvested silage was submitted to the following treatments: silage of Marandu grass immediately after cut; silage of Marandu grass $+50 \mathrm{~g} / \mathrm{kg}$ of pelleted citrus pulp (PCP) and Marandu grass silage $+100 \mathrm{~g} / \mathrm{kg}$ PCP as natural matter basis. Pelleted citrus pulp was added to and completely homogenized with the forage just before filling the silos.

Metal containers with $80 \mathrm{~cm}$ of height and $50 \mathrm{~cm}$ of diameter were used as silos. Forage was compacted by human treading, adjusting layers with $20 \mathrm{~cm}$ of thickness, achieving a density of $900 \mathrm{~kg} / \mathrm{m}^{3}$. After the last forage additions, silos were closed with plastic canvas, sealed with plastic adhesive tape and stored in a sheltered place at room temperature.

Silos were opened after 178 days to evaluate chemical the composition and microbiological dynamics of silages from each treatment using total microorganism counts at 0 , 2, 4 and 6 days after breaking the seal. Silos were thus managed so that time zero was the opening. A layer of approximately $15 \mathrm{~cm}$ was taken at each two days to collect samples for analysis.

Immediately after silos were opened, approximately $3 \mathrm{~kg}$ of silage were sampled and put in seven-liter styrofoam boxes, which were taken to the climatic chamber at $25 \pm 1^{\circ} \mathrm{C}$ to evaluate the aerobic stability. Silage temperature was measured at 0, 24, 48, 72, 96, 120, 144 and 168 hours after placing the boxes in the climatic chamber, using a thermometer inserted $10 \mathrm{~cm}$ in the center of the silage mass. Environment temperature was monitored with the thermostat from the refrigerator and with suspended thermometers inside the chamber. The aerobic stability was considered as the time elapsed so that the temperature of the feed increased two degrees when compared to the environment temperature, after the silo was opened.

During silo feedout, samples were collected and divided into three portions. The first fraction was used in chemical analysis. Dry matter (DM) and in vitro dry matter digestibility (IVDMD) were estimated using method described by Tilley \& Terry (1963). The second fraction from each sample was used for juice extraction through hydraulic press. Ammonia nitrogen levels $\left(\mathrm{N}-\mathrm{NH}_{3}\right)$ were determined in the extracted juice and $\mathrm{pH}$ was determined through pH meter (Silva, 1998). The last fraction was used in the microbiological analysis.

Samples were prepared for analysis by diluting $25 \mathrm{~g}$ of silage (natural matter) in $225 \mathrm{~mL}$ of sterile saline (8.5 g $\mathrm{NaCl} /$ liter of distilled water). After mixing, $10 \mathrm{~mL}$ of the extract was further diluted to $10^{-1}$ to $10^{-8}$ and plated in media specific for each studied microorganism. 
Bacillus was evaluated according to Speck (1976), using nutrient agar (Difco) and anaerobic incubation for three days at $30^{\circ} \mathrm{C}$. Enterobacteria were evaluated in Violet Red Bile Agar (Oxoid) under anaerobiosis for three days at $35^{\circ} \mathrm{C}$, according to Jonsson (1991). Total yeast counting was performed according to Van der Walt \& Yarrow (1984). Samples were incubated for three days at $28^{\circ} \mathrm{C}$ in YN medium (Difco), acidified with lactic acid ( $\mathrm{pH}$ 4.0). Mold counting was performed using the same medium and temperature, but samples were incubated for 6 days. Yeast and molds were separated based on the physical appearance of colonies; yeast form unicellular colonies whereas fungi are filamentous multicellular organisms.

After yeast count, colonies that were evidently distinct according to morphological criteria were categorized (Table 1). In the present study, six wild yeast strains were

Table 1 - Morphological colony characteristics used in the evaluation of isolated strains

\begin{tabular}{lc}
\hline Characteristic & Description \\
\hline Size & diameter (mm) \\
Texture & mucoid, viscous, bright, opaque \\
Color & white, cream, pink, purple, etc. \\
Surface & smooth, rough, complex \\
Border & smooth, wavy, dented, filiform, rhizoid \\
Elevation & convex, conic, flat, elevated, drop, umbilicated \\
\hline
\end{tabular}

categorized, named M01, M02, M03, M04, M05 and M06. Cultures were transferred into GYMP slants (Difco) and kept under refrigeration.

Refrigerated stock cultures in GYMP slants were used in the following tests, according to Van der Walt \& Yarrow (1984):

a) Test of carbon source assimilation in $10 \mathrm{x}$ concentrated liquid media. Glucose, fructose, xylose, L-arabinose and lactate were used as carbon sources;

b) Fermentation test using glucose, fructose, xylose, L-arabinose and lactate as carbon source.

A split-plot design in a completely randomized design with four repetitions was used. Treatments were the parcels and time was the sub-parcel. Data were analyzed by ANOVA (SAS, 1999). Means were compared by Tukey test $(\mathrm{P}<0.05)$.

\section{Results and Discussion}

Enterobacteria were detected in the silage containing 0 g/kg PCP and increased after silo opening $(\mathrm{P}<0.05)$, but this behavior was not similar to that observed in silages containing 5 and $100 \mathrm{~g} / \mathrm{kg}$ PCP. Bacillus growth in the silages was similar to the behavior seen for enterobacteria (Table 2). There was an increase in Bacillus growth during silo feedout in the silage containing $0 \mathrm{~g} / \mathrm{kg} \mathrm{PCP}$; Bacillus were not seen in the other treatments $(\mathrm{P}<0.05)$.

Silages containing 50 and $100 \mathrm{~g} / \mathrm{kg}$ PCP showed yeast growth (Table 3), which increased during silo feedout $(\mathrm{P}<0.05)$. Mold growth was only detected in silages containing $100 \mathrm{~g} / \mathrm{kg}$ PCP when the silos were opened (2.4 log cfu/g silage).

The mean $\mathrm{pH}$ of silages without PCP (5.2) possibly favored the enterobacterium growth. Besides, the reduction of the water activity $\left(a_{w}\right)$ of silages added with PCP may be inhibiting the development of this kind of bacteria, since gram negative microorganisms prefer an environment with high $\mathrm{a}_{\mathrm{w}}$ levels (0.98).

According to Ostling \& Lindgren (1995), during aerobic deterioration of silages, enterobacteria have the opportunity to restart their growth significantly. Lindgren et al. (1985) studied the aerobic deterioration of grass silages and grass silages mixed with legumes and reported an increase in the number of enterobacteria after air exposure, which was even stronger at temperatures around $30^{\circ} \mathrm{C}$ and in the silo surface when compared to samples collected $30 \mathrm{~cm}$ deeper. The authors concluded that silages sampled on the surface of the silos showed higher $\mathrm{pH}$ levels and lower lactic acid levels, comprising a better environment for the growth of such bacteria.

As for Bacillus growth, this may also result from the $\mathrm{pH}$ influence on the bacterial growth, since Bacillus do not tolerate the slightly acid substrate $(\mathrm{pH}<4.2)$ characteristic of silages with additives.

Table 2 - Enterobacterium and Bacillus growth (log cfu/g silage) during silo feedout in Marandu grass silage added with pelleted citrus pulp (PCP)

\begin{tabular}{|c|c|c|c|c|c|}
\hline \multirow[t]{2}{*}{ Silage (g/kg PCP) } & \multicolumn{4}{|c|}{ Time (days) } & \multirow{2}{*}{$\begin{array}{c}\text { CV (\%) } \\
2.62\end{array}$} \\
\hline & 0 & 2 & 4 & 6 & \\
\hline & \multicolumn{4}{|c|}{ Enterobacteria } & \\
\hline 0 & 3.9Ab & $4.0 \mathrm{Ab}$ & $4.1 \mathrm{Ab}$ & 4.5Aa & \\
\hline 50 & $<2.0 \mathrm{Ba}$ & $<2.0 \mathrm{Ba}$ & $<2.0 \mathrm{Ba}$ & $<2.0 \mathrm{Ba}$ & \\
\hline \multirow[t]{2}{*}{100} & $<2.0 \mathrm{Ba}$ & $<2.0 \mathrm{Ba}$ & $<2.0 \mathrm{Ba}$ & $<2.0 \mathrm{Ba}$ & \\
\hline & \multicolumn{4}{|c|}{ Bacillus } & \\
\hline 0 & $<2.0 \mathrm{Ab}$ & 2.1Ab & 2.8Bb & 3.2Ba & \\
\hline 50 & $<2.0 \mathrm{Aa}$ & $<2.0 \mathrm{Aa}$ & $<2.0 \mathrm{Aa}$ & $<2.0 \mathrm{Aa}$ & \\
\hline 100 & $<2.0 \mathrm{Aa}$ & $<2.0 \mathrm{Aa}$ & $<2.0 \mathrm{Aa}$ & $<2.0 \mathrm{Aa}$ & \\
\hline CV (\%) & 1.56 & & & & \\
\hline
\end{tabular}

Means with same capital letters in the columns and small letters in the rows are not different $(\mathrm{P}>0.05)$ by Tukey test. 
Table 3 - Yeast and mold growth (log cfu/g silage) during silo feedout in Marandu grass silages added with pelleted citrus pulp (PCP)

\begin{tabular}{|c|c|c|c|c|c|}
\hline \multirow[t]{2}{*}{ Silage (g/kg PCP) } & \multicolumn{4}{|c|}{ Time (days) } & \multirow{2}{*}{$\begin{array}{c}\text { CV (\%) } \\
3.03\end{array}$} \\
\hline & 0 & 2 & 4 & 6 & \\
\hline & \multicolumn{4}{|c|}{ Yeast } & \\
\hline 0 & $<2.0 \mathrm{Ba}$ & $<2.0 \mathrm{Ba}$ & $<2.0 \mathrm{Ba}$ & $<2.0 \mathrm{Ba}$ & \\
\hline 50 & $2.0 \mathrm{Ba}$ & 2.3Аа & $2.2 \mathrm{Ba}$ & 2.3Ba & \\
\hline \multirow[t]{2}{*}{100} & $2.4 \mathrm{Ab}$ & $2.4 \mathrm{Ab}$ & 2.7Aa & $2.8 \mathrm{Aa}$ & \\
\hline & \multicolumn{4}{|c|}{ Molds } & \\
\hline 0 & $<2.0 \mathrm{Ba}$ & $<2.0 \mathrm{Aa}$ & $<2.0 \mathrm{Aa}$ & $<2.0 \mathrm{Aa}$ & \\
\hline 50 & $<2.0 \mathrm{Ba}$ & $<2.0 \mathrm{Aa}$ & $<2.0 \mathrm{Aa}$ & $<2.0 \mathrm{Aa}$ & \\
\hline 100 & $2.4 \mathrm{Aa}$ & $<2.0 \mathrm{Ab}$ & $<2.0 \mathrm{Ab}$ & $<2.0 \mathrm{Ab}$ & \\
\hline CV (\%) & 1.77 & & & & \\
\hline
\end{tabular}

Means with same capital letters in the columns and small letters in the rows are not different $(\mathrm{P}>0.05)$ by Tukey test.

Woolford (1990) reported that Bacillus was firstly believed to have a secondary function when compared to yeast in silage deterioration. Nonetheless, many studies have evidenced that these microorganisms exert a function that is far more important than previously believed for the same forage species. Many studies conducted in North America and Europe have shown that bacteria from the genus Bacillus are in the silages at the final phases of deterioration, and when yeasts have consumed lactic acid and feed, $\mathrm{pH}$ levels are high. Nevertheless, tropical environments enable favorable conditions for the development of this kind of bacterium, since forages are characterized by a fermentation process in which $\mathrm{pH}$ values stabilize over 4.5 .

The presence of Bacillus changes significantly the chemical composition of silages, especially in protein content, since the majority of Bacillus species is proteolytic. The most important species involved in aerobic deterioration is Bacillus cereus (Granum, 1997). According to McDonald et al. (1991), the loss of aminoacids in silages indicates the production of nitrogen compounds such as polyamines. Steidlová \& Kalac (2002) evaluated the production of polyamines in corn silages produced in farms and reported that tyramine, cadaverine and putrescine added up to $90 \%$ of the total of polyamines.

In a review, Charmley (2001) reported that fermentation products have determined a decrease in ingestion when cultures are ensiled, and in some studies, the decrease in intake is mainly related to the nitrogen fractions. Nussio et al. (2002) have alerted that recent studies have used supplementation with specific aminoacids in order to compensate the low protein levels in the food, instead of feeding a supplement with high protein level.
The yeast growth in the present study was similar to results reported in literature; immediately after oxygen enters the silo, there is an intense activity of aerobic microorganisms, especially yeast, beginning the deterioration process (Lindgren et al. 1985; Jobim et al., 1999; Guim et al., 2002; Ashbell et al., 2002). The yeast population may increase steeply from $2.0 \mathrm{log} \mathrm{cfu} / \mathrm{g}$ silage to $12.0 \mathrm{log} \mathrm{cfu} / \mathrm{g}$ silage in only three days of aeration (Pitt et al. 1991). Silages with yeast population above $5.0 \mathrm{log} \mathrm{cfu} / \mathrm{g}$ silage are highly susceptible to deterioration (Woolford, 1990); therefore, silages in the present study may be classified as nonsusceptible to fast deterioration if only the number of yeast present in the feed is considered.

Silages with $0 \mathrm{~g} / \mathrm{kg}$ PCP showed no yeast growth, which might be explained by the lack of substrate for the microorganisms, so that PCP supplementation may guarantee nutrient for their assimilation and, consequently, later growth, either by the higher lactic acid levels in the supplemented silages or by the presence of pectin. Walker (1998) and Blanco et al. (1999) reported that Candida and Cryptococcus species use pectic substances efficiently as carbon source in the cellular metabolism, and, according to Woolford (1990), these are the two main genus involved in the aerobic deterioration process.

Another explanation for the absence of yeast in the control silages would be the presence of acetic and propionic acids that are produced during the fermentation process and also after the breakage of the seal. According to Corlett Jr. \& Brown (1980), different acids may exert an inhibitory or lethal effect on the microbe cell, because in optimum substrate condition and close to neutrality, the internal $\mathrm{pH}$ of the cell is close to 7.0. Nevertheless, such value is extremely affected by external changes and the microbe inhibition is due to the hydrogen ion concentration (free $\mathrm{H}^{+}$) or by the toxicity of the non-dissociated acid. Walker (1998) reported that non-dissociated organic acids (acetic, propionic) are easily soluble in the yeast cell membrane, releasing $\mathrm{H}^{+}$and consequently inhibiting the microorganism (Figure 1).

In order to keep an adequate internal $\mathrm{pH}$, the yeast cell exports $\mathrm{H}^{+}$that is stored inside the cell using the ATPase enzyme and consuming energy during the process. The energy spent in this process results in reduced cell growth or even death, since ATPase is the most important enzyme in yeast cells, responsible for the control of cell $\mathrm{pH}$, nutrients and ion transport (Walker, 1998).

It is worth noting that the research studies in the past few years have been carried out using silages with high levels of nutrients (Kung \& Ranjit, 1998; Higginbotham et 


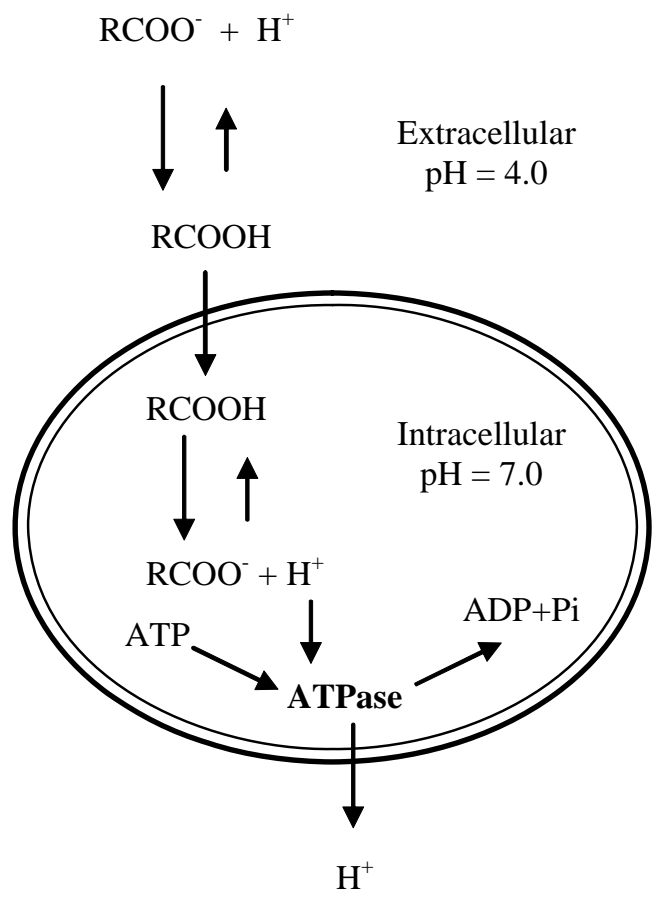

Figure 1 - Fate of organic acid in an environment of low $\mathrm{pH}$ and in the presence of microbe cells. Adapted from Davidson (1997).

al., 1998; Driehuis et al., 2001). Such studies have evaluated bacteria such as Lactobacillus buchneri and Propionibacterium acidipropionici, which are able to produce not only lactic acid during the fermentation process, but also acetate and propionate by means of the heterolactic fermentation way route. In such way, these bacteria may reduce the presence of microorganisms (mainly yeast) that cause deterioration after silo opening.

The absence of yeast in the non-added silages may also be explained by the microorganism-microorganism interaction. According to Woolford (1990), one of the genuses that increase during aerobic deterioration is Streptomyces. Walker (1998) reported that the presence of these bacteria inhibits the yeast growth because they produce compounds such as cycloheximides, which are lethal to microbe cells.

As for the occurrence of filamentous fungi, it can be inferred that the presence of oxygen on the upper part of the silo caused this behavior. The difficulty in compacting this area during ensiling favored oxygenation, and consequently, the occurrence of molds.

According to Muck et al. (1991), molds have slower growth when compared to yeast, and usually they present lower population during storage due to their higher susceptibility to the absence of oxygen.

After exposure of the silage to air, there are important indicators of deterioration of the ensiled mass: increase in temperature, decrease in soluble carbohydrate levels, low lactic acid concentration, and increase in $\mathrm{pH}$ (Pitt et al., 1991; Higginbotham et al., 1998).

The digestibility was influenced by PCP addition so that higher digestion levels were seen in silages containing this additive. During silo feedout, the silage digestibility decreased $(\mathrm{P}<0.05)$, evidencing a decrease in the nutritional value due to feed deterioration (Table 4).

According to McDonald et al. (1991), energy losses by aerobic deterioration after silo opening may be over $15 \%$. In the present study, IVDMD was reduced in 5\% from silo opening until the sixth day of aeration, evidencing that the silo feedout is an important cause of nutrient loss during the ensiling process. Nussio et al. (2002) reported that after silo opening, the instability must be considered as an additional means of loss of dry matter and energy and, as such, it should be added to inherent losses of the production system.

The silages presented different $\mathrm{pH}$ levels when silos were opened (Figure 2), so that PCP decreased pH. After the seal was broken, silages with 0 and $50 \mathrm{~g} / \mathrm{kg}$ PCP had an increase in $\mathrm{pH}(\mathrm{P}<0.05)$. The treatment with $100 \mathrm{~g} / \mathrm{kg}$ PCP showed a slight decrease after two days of unsealing, but it was stable afterwards ( 4 and 6 days).

$\mathrm{pH}$ increase in silages containing 0 and $50 \mathrm{~g} / \mathrm{kg}$ PCP may be related to lactic acid use by deteriorating microorganisms. Nevertheless, the $\mathrm{pH}$ behavior that was seen in silages with $100 \mathrm{~g} / \mathrm{kg}$ PCP was not expected, since these silages theoretically have higher carbohydrate and lactic acid levels to be consumed when compared to the other silages. Probably, the high density of this treatment $\left(260 \mathrm{~kg} \mathrm{DM} / \mathrm{m}^{3}\right)$ has lead to low porosity, preventing silage oxygenation on deeper layers of the silo. Nevertheless, the growth of the

Table 4 - Dry matter (DM), $\mathrm{pH}$, ammonia nitrogen $\left(\mathrm{N}-\mathrm{NH}_{3}\right)$ and in vitro digestibility of dry matter (IVDMD) levels during silo feedout of Marandu grass silages added with pelleted citrus pulp (PCP)

\begin{tabular}{lcccc}
\hline $\begin{array}{l}\text { Silage } \\
(\mathrm{g} / \mathrm{kg} \text { PCP) }\end{array}$ & $\begin{array}{c}\mathrm{DM} \\
(\mathrm{g} / \mathrm{kg})\end{array}$ & $\mathrm{pH}$ & $\begin{array}{c}\mathrm{N}-\mathrm{NH}_{3} \\
(\mathrm{~g} / \mathrm{kg} \text { total } \mathrm{N})\end{array}$ & $\begin{array}{c}\text { IVDMD } \\
(\mathrm{g} / \mathrm{kg} \mathrm{DM})\end{array}$ \\
\hline 0 & $205 \mathrm{C}$ & $4.9 \mathrm{~A}$ & $228 \mathrm{~A}$ & $423 \mathrm{C}$ \\
5 & $233 \mathrm{~B}$ & $4.5 \mathrm{~B}$ & $139 \mathrm{~B}$ & $547 \mathrm{~B}$ \\
10 & $265 \mathrm{~A}$ & $4.1 \mathrm{C}$ & $87 \mathrm{C}$ & $631 \mathrm{~A}$ \\
$\mathrm{CV}(\%)$ & 3.7 & 2.9 & 26.1 & 3.7 \\
\hline \multicolumn{5}{c}{ Time } \\
0 & $234 \mathrm{~B}$ & $4.5 \mathrm{~B}$ & $152 \mathrm{C}$ & $551 \mathrm{~A}$ \\
2 & $254 \mathrm{~A}$ & $4.7 \mathrm{AB}$ & $156 \mathrm{C}$ & $541 \mathrm{~A}$ \\
4 & $252 \mathrm{~A}$ & $4.8 \mathrm{AB}$ & $243 \mathrm{~B}$ & $540 \mathrm{~A}$ \\
6 & $248 \mathrm{AB}$ & $4.9 \mathrm{~A}$ & $319 \mathrm{~A}$ & $523 \mathrm{~B}$ \\
$\mathrm{CV}(\%)$ & 3.2 & 3.0 & 10.2 & 4.9 \\
\hline
\end{tabular}

Means with same superscript letter in columns are not different $(\mathrm{P}>0.05)$ by Tukey test. 


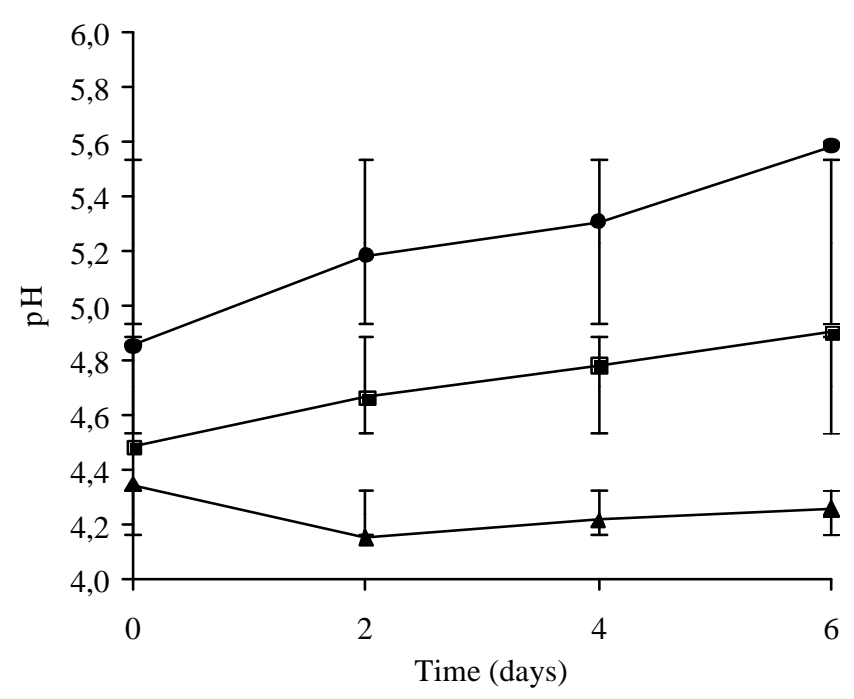

Figure 2 - pH levels of Marandu grass silages added with $0(\bullet)$, $50(\boldsymbol{\square})$ and $100(\boldsymbol{\Delta}) \mathrm{g} / \mathrm{kg}$ of pelleted citrus pulp during silo feedout.

main deteriorating microorganism, yeast, has increased during silo feedout. Ashbell \& Lisker (1988) studied the aerobic deterioration of corn silages in bunker silos and reported similar results, so that deeper layers presented lower $\mathrm{pH}$ values when compared to exposed layers.

Guim et al. (2002) used the PET system to evaluate deterioration in elefante grass silage (Pennisetum purpureum Schum.) for a eight-day exposure period and also reported increase in $\mathrm{pH}$ levels, from 3.9 at silo opening to 5.8 at the eighth day of aeration. Lindgren et al. (1985) worked with grass silages in bunker silos and reported 4.0 vs $6.4 ; 4.0$ vs 4.5 and 4.0 vs $4.0 \mathrm{pH}$ values on silages at the day of opening and eight days after air exposure, for layers $0-15 \mathrm{~cm}$; 40-60 cm and 140-160 cm, respectively. The same study reported a significant reduction on yeast, Bacillus and enterobacterium populations in the deepest layer $(140-160 \mathrm{~cm})$, which shows potential changes that the microorganisms might have caused to the food.

It must be noted that, besides leading to favorable niches for subsequent microorganisms, the use of lactic acid by the organisms that begin the deterioration process also reduce the nutritional value of feed. According to Chamberlain (1987), lactic acid from the silage fermentation process is the best product used in the ruminal environment, compared to other organic acids present on silage. The ruminal bacterium Megasphaera elsdenii produces 2 ATPs when lactic acid is fermented, which may contribute to microorganism maintenance and growth. On the other hand, ruminal microorganisms do not use acetic acid and butyric acid (Van Soest, 1994; Russell \& Rychlik, 2001).
Cumulative temperature data of the first seven days after silo opening are shown in Table 5. The three silages were stable considering the parameter evaluated in the study, i.e., one degree above room temperature $\left(25^{\circ} \mathrm{C}\right)$. Nevertheless, the temperature tends to increase with aerobic exposure, mainly on the treatment added with $100 \mathrm{~g} / \mathrm{kg}$ PCP.

Silages with higher nutrient levels are less stable, which may be proved by the fact that the recovered dry matter levels (RDM) are lower in silages added with $100 \mathrm{~g} / \mathrm{kg}$ PCP.

The PCP inclusion during ensiling promoted higher temperature profiles. This might have been due to the higher levels of nutrients (lactic acid and carbohydrates) available to aerobic microorganisms, mainly yeast, as previously discussed. According to Ashbell et al. (2002), the most important factors that affect the aerobic silage stability are the presence of oxygen and substrate and the temperature the feed is submitted to.

Igarasi (2002) evaluated the aerobic stability of Tanzania grass silages (Panicum maximum Jacq. cv. Tanzânia) through the temperature accumulated during 5 days after silo opening, and reported that the treatment added with PCP showed higher accumulated temperature than the control silage, corroborating datadescribe here. Balsalobre et al. (2001) reported that silages of more finely chopped Tanzania grass supplemented with PCP tended to have more aerobic stability when compared to the treatment with larger particles and without PCP.

Bernardes et al. (2007) evaluated the effects of the chemical and heterofermentative bacteria additives on the aerobic stability of the Marandu grass silage, and reported that the temperature of silages showed little changes during the six day of air exposure.

Table 5 - Increase in temperature and recovered dry mater (RDM) from Marandu grass silages added with pelleted citrus pulp (PCP)

\begin{tabular}{lccccc}
\hline \multirow{2}{*}{ Time (days) } & \multicolumn{3}{c}{ Silages $(\mathrm{g} / \mathrm{kg}$ PCP) } & Mean & CV (\%) \\
\cline { 2 - 4 } & 0 & 50 & 100 & & \\
\hline 0 & $19.7 \mathrm{Ca}$ & $19.9 \mathrm{Aa}$ & $19.9 \mathrm{Ca}$ & $19.8 \mathrm{D}$ & 1.32 \\
1 & $19.3 \mathrm{Cc}$ & $21.5 \mathrm{Ab}$ & $22.3 \mathrm{Ba}$ & $21.0 \mathrm{CD}$ & - \\
2 & $19.3 \mathrm{Cc}$ & $21.6 \mathrm{Ab}$ & $22.6 \mathrm{Ba}$ & $21.2 \mathrm{CD}$ & - \\
3 & $20.4 \mathrm{Bc}$ & $21.9 \mathrm{Ab}$ & $23.0 \mathrm{Aa}$ & $21.8 \mathrm{C}$ & - \\
4 & $20.6 \mathrm{Bc}$ & $21.5 \mathrm{Ab}$ & $23.0 \mathrm{Aa}$ & $21.8 \mathrm{C}$ & - \\
5 & $20.8 \mathrm{Bc}$ & $21.6 \mathrm{Ab}$ & $23.7 \mathrm{Aa}$ & $22.0 \mathrm{CB}$ & - \\
6 & $21.4 \mathrm{Ac}$ & $21.9 \mathrm{Ab}$ & $24.0 \mathrm{Aa}$ & $22.4 \mathrm{~B}$ & - \\
7 & $21.6 \mathrm{Ab}$ & $22.0 \mathrm{Ab}$ & $25.0 \mathrm{Aa}$ & $22.9 \mathrm{~A}$ & - \\
Mean & $20.4 \mathrm{c}$ & $21.4 \mathrm{~b}$ & $23.0 \mathrm{a}$ & - & - \\
CV $(\%)$ & 1.89 & - & - & - & - \\
RDM $(\%)$ & $91.3 \mathrm{a}$ & $91.0 \mathrm{a}$ & $90.4 \mathrm{~b}$ & - & 0.71 \\
\hline
\end{tabular}

Means with same capital letters in the columns and small letters in the rows are not different $(\mathrm{P}>0.05)$ by Tukey test. 
Isolated yeast strains showed many different characteristics (Table 6). A slight variation in colony size was seen (1 to $4 \mathrm{~mm}$ ) and all colonies were smooth and convex, but texture, border and color were different.

The results of carbon source assimilation (Table 7) showed that different strains present diverse results. Strains M03, M04 and M06 showed not only glucose and fructose assimilation, the two most abundant structural carbohydrates in plants, but they also assimilated arabinose, xylose and lactate.

No strain was able to ferment arabinose, xylose and lactate (Table 8); only glucose and fructose fermentation occurred, although in low levels.

Besides glucose and fructose, strains M03, M04 and M06 also assimilated arabinose and xylose. Free pentosans are present in low levels in forages, but these levels might increase by acid hydrolysis and hemicellulase activity that occur during fermentation. According to Van Soest (1994), analysis of the sugar compounds produced by hemicellulose hydrolysis evidences the presence of xylose and arabinose. Prior \& Kotter (1997) reported that pentosans are converted into xylose-5-phosphate, which can be transformed into acetylphosphate during acetate or glyceraldehyde-3phosphate during ethanol production. According to Walker (1998), pentosans metabolism in yeast depends on the species (presence of enzyme) and nutritional status of the organism. For example, glucose generally decreases yeast assimilation of other sugars.

Table 6 - Morphological aspects of strain colonies

\begin{tabular}{lcccccc}
\hline Strain & Size $(\mathrm{mm})$ & Texture & Surface & Border & Elevation & Color \\
\hline M01 & $2-4$ & bright & smooth & dented & convex & beige \\
M02 & $2-4$ & bright & smooth & dented & convex & beige \\
M03 & $2-4$ & bright & smooth & dented & convex & beige \\
M04 & $1-2$ & opaque & smooth & smooth & convex & white \\
M05 & $2-4$ & bright & smooth & dented & convex & beige \\
M06 & $1-2$ & opaque & smooth & smooth & convex & white \\
\hline
\end{tabular}

Table 7 - Behavior of yeast strains in carbon source assimilation test

\begin{tabular}{lccccc}
\hline Strain & \multicolumn{5}{c}{ Carbon source } \\
\cline { 2 - 6 } & Glucose & Fructose & Arabinose & Xylose & Lactate \\
\hline M01 & + & + & - & - & + \\
M02 & + & + & - & - & + \\
M03 & + & + & + & + & + \\
M0 4 & + & + & + & + & + \\
M05 & + & + & - & - & + \\
M06 & + & + & + & + & + \\
\hline
\end{tabular}

Assimilation: positive (+); negative (-).
Table 8 - Strain behavior in basal fermentation media

\begin{tabular}{lccccc}
\hline Strain & \multicolumn{5}{c}{ Carbon source } \\
\cline { 2 - 6 } & Glucose & Fructose & Arabinose & Xylose & Lactate \\
M01 & $+\mathrm{W}$ & $+\mathrm{W}$ & - & - & - \\
$\mathrm{M} 02$ & $+\mathrm{W}$ & $+\mathrm{W}$ & - & - & - \\
$\mathrm{M} 03$ & $+\mathrm{W}$ & $+\mathrm{W}$ & - & - & - \\
$\mathrm{M} 04$ & $+\mathrm{W}$ & $+\mathrm{W}$ & - & - & - \\
$\mathrm{M} 05$ & $+\mathrm{W}$ & $+\mathrm{W}$ & - & - & - \\
M06 & $+\mathrm{W}$ & $+\mathrm{W}$ & - & - & - \\
\hline
\end{tabular}

Fermentation: weak (+W); negative (-).

All strains were able to assimilate glucose, fructose and lactate. Gancedo \& Serrano (1989) reported that, when the microbe cell uptakes the lactic acid, it is oxidized into pyruvate, induced by L-lactate:cytocrome $c$ oxyredutase, an enzyme located on the internal mitochondrial membrane in yeast.

According to Woolford (1990), yeast population that uses lactate as energy source determines if the silage may or may not deteriorate during air exposure. Thus, a great population does not necessarily mean that there will be a fast deterioration. Lindgren et al. (1985) reported seven yeast species during aerobic exposure of grass silages in temperate climate, such that Candida lambica, Candida krusei and Hansenula anomala showed lactic acid assimilation during laboratory tests. Pahlow et al. (2003) reported that, from the aerobic microorganisms present during deterioration, yeast genus Hansenula and Candida are the most important because of lactate assimilation.

\section{Conclusions}

Bacillus and enterobacteria are present on Marandu grass silages without pelleted citrus pulp, which also show $\mathrm{pH}$ increase throughout the feedout phase. Yeasts are present on silages with pelleted citrus pulp as fermentation stimulating agent. The trend in temperature increase with extension of aeration time occurs mainly in silages containing pelleted citrus pulp.

\section{Acknowledgments}

The authors wish to thank Márcia Justino Rossini Mutton (Universidade Estadual Paulista, Jaboticabal, São Paulo, Brazil) for her contribution during microbiological analyses. 


\section{Literature Cited}

ASHBELL, G.; LISKER, N. Aerobic deterioration in maize silage stored in a bunker silo under farm conditions in a subtropical climate. Journal Science Food Agriculture, v.45, p.307-315, 1988.

ASHBELL, G.; WEINBERG, Z.G.; HEN, Y. et al. The effects of temperature on the aerobic stability of wheat and corn silages. Journal Industrial Microbiology and Biotechnology, v.28, p.261-263, 2002.

BALSALOBRE, M.A.A.; NUSSIO, L.G.; MARTHA JR., G.B. Controle de perdas na produção de silagens de gramíneas tropicais. In: REUNIÃO ANUAL DA SOCIEDADE BRASILEIRA DE ZOOTECNIA, 38., 2001, Piracicaba. Anais... Piracicaba: Sociedade Brasileira de Zootecnia, 2001. p.890-911.

BERNARDES, T.F.; REIS, R.A.; SIQUEIRA, G.R. et al. Estabilidade aeróbia da ração total e de silagens de capim-marandu tratadas com aditivos químicos e bacterianos. Revista Brasileira de Zootecnia, v.36, p.754-762, 2007.

BEN-GHEDALIA, D.; MIRON, J.; YOSEF, E. Fermentation of alfalfa silages with ozonated cotton stilks added. Journal Agricultural Food Chemistry, v.39, p.2002-2005, 1991.

BLANCO, P.; SIEIRO, C.; VILLA, T.G. Production of pectic enzymes in yeast. FEMS Microbiology Letters, v.175, p.1-9, 1999.

CHAMBERLAIN, D.G. The silage fermentation in relation to the utilization of nutrients in the rumen. Process Biochemistry, v.1, p.60-63, 1987.

CHARMLEY, E. Towards improved silage quality - a review. Canadian Journal Animal Science, v.81, p.157-168, 2001.

CORLETT JR., D.A.; BROWN, M.H. pH and acidity. In: ICMSF (Ed). Microbial ecology of foods. New York: Academic Press, 1980. p.92-111.

DAVIDSON, P. M. Chemical preservatives and natural antimicrobial compounds. In: DOYLE, M.P.; BEUCHAT, L.R.; MONTVILLE, T.J. (Eds.). Food microbiology: fundamentals and frontiers. Washington: ASM Press, 1997. p.520-556.

DRIEHUIS, F.; OUDE ELFERINK, W.H.; Van WIKSELAAR, P.G. Fermentation characteristics and aerobic stability of grass silage inoculant with Lactobacillus buchneri, with or without mofermentative lactic acid bacteria. Grass and Forage Science, v.56, p.330-343, 2001.

GANCEDO, C.; SERRANO, R. Energy-yielding metabolism. In: ROSE, A.H.; HARRISON, J.S. (Eds.). The yeasts: metabolism and physiology of yeasts. London: Academic Press, 1989. p.205-260.

GRANUM, P.E. Foodborne pathogenic bacteria: Bacillus cereus. In: DOYLE, M.P.; BEUCHAT, L.R.; MONTVILLE, T.J. (Eds.). Food microbiology: fundamentals and frontiers. Washington: ASM Press, 1997. p.327-336.

GUIM, A.; ANDRADE, P.; ITURRINO, R.P.S. et al. Estabilidade aeróbica de silagens de capim elefante (Pennisetum purpureum, Schum) emurchecido e tratado com inoculante microbiano. Revista Brasileira de Zootecnia, v.31, p.2176-2185, 2002.

HIGGINBOTHAM, G.E.; MUELLER, S.C.; BOLSEN, K.K. et al. Effects of inoculants containing propionic acid bacteria on fermentation and aerobic stability of corn silage. Journal of Dairy Science, v.81, p.2185-2192, 1998.

IGARASI, M.S. Controle de perdas na ensilagem de capimTanzânia (Panicum maximum Jacq. Cv. Tanzânia) sob os efeitos do teor de matéria seca, do tamanho de partícula, da estação do ano e da presença do inoculante bacteriano. 2002. 132f. Dissertação (Mestrado em Ciência Animal e Pastagens) - Escola Superior de Agricultura/Universidade de São Paulo, Piracicaba, 2002.
JONSSON, A. Growth of Clostridium tyrobutiricum during fermentation and aerobic deterioration of grass silage. Journal Science Food Agriculture, v.54, p.557-568, 1991.

KUNG, L., JR.; STOKES, M.R.; LIN, C.J. Silage additives. In: BUXTON, D.R.; MUCK, R.E.; HARRISON, J.H. (Eds.) Silage science and technology. 1.ed. Madison: American Society of Agronomy, 2003. p.305-360.

KUNG JR., L.; RANJIT, N.K. The effect of Lactobacillus buchneri and other additives on the fermentation and aerobic stability of barley silage. Journal of Dairy Science, v.84, p.1149-1155, 1998.

LIDGREN, S.; PETTERSSON, K.; KASPERSON, A. et al. Microbial dynamics during aerobic deterioration of silages. Journal Science Food Agriculture, v.36, p.765-774, 1985.

McDONALD, P.; HENDERSON, A.R.; HERON, S.J.E. Biochemistry of silage. 2.ed. Marlow: Chalcombe Publication, 1991. 340p.

MUCK, R.E.; PITT, R.E.; LEIBENSPERGER, R.Y. A model of aerobic fungal growth in silage. 1. Microbial characteristics. Grass and Forage Science, v.46, p.283-296, 1991.

NUSSIO, L.G.; PAZIANI, S.F.; NUSSIO, C.M.B. Ensilagem de gramíneas tropicais. In: REUNIÃO ANUAL DA SOCIEDADE BRASIlEIRA DE ZOOTECNIA, 39., 2002, Recife. Anais.. Recife: Sociedade Brasileira de Zootecnia, 2002. p.60-99.

OSTLING, C.; LINDGREN, S. Influences of enterobacteria on the fermentation and aerobic stability of grass silages. Grass and Forage Science, v.50, p.41-47, 1995.

PAHLOW, G.; MUCK, R.E.; DRIEHUIS, F. et al. Microbiology of ensiling. In: BUXTON, D.R.; MUCK, R.E.; HARRISON, J.H. (Eds.) Silage science and technology. Madison: American Society of Agronomy, 2003. p.31-94.

PITT, R.E.; MUCK, R.E.; PICKERING, N.B. A model of aerobic fungal growth in silage. 2. Aerobic stability. Grass and Forage Science, v.46, p.301-312, 1991.

PRIOR, B.A.; KOTTER, P. Pentose utilization by yeasts. In: ZIMMERMAN, F.K.; ENTIAN, K.D. (Eds.) Yeast sugar metabolism: biochemistry, genetics, biotechnology and applications. Lancaster: Technomic Publishing, 1997. p.435-457.

RUSSELL, J.B.; RYCHLIK, J.L. Factors that alter rumen microbial ecology. Science, v.292, p.1119-1122, 2001.

STATISTICAL ANALYSES SYSTEM - SAS. SAS/STAT: user's guide. Version 8. Cary: 1999. (CD-ROM).

SILVA, D.J. Análise de alimentos: métodos químicos e biológicos. 2.ed. Viçosa, MG: Universidade Federal de Viçosa, 1998. 166p.

SPECK, M.L. Compedium of methods for the microbiological examination of foods. Washington: American Public Health Association, 1976. 77p.

STEIDLOVÁ, S.; KALAC, P. Levels of biogenic amines in maize silages. Animal Feed Science and Technology, v.102, p.197205, 2002.

TILLEY, J.M.A.; TERRY, R.A. A two-stage tecnique for the in vitro digestion of forage crops. Journal British Grassland, v.18, p.104-111, 1963.

Van der WALT, R.P.; YARROW, D. Methods for the isolation, maintenance, classification and identification of yeast. In: KURTMAN, C.P.; FELL, J.W. (Eds.) The yeast: a taxonomic study. Amsterdam: Elsevier Science Published, 1984. p.45-62.

Van SOEST, J.P. Nutritional ecology of the ruminant. New York: Cornell University Press, 1994. 476p.

WALKER, G.M. Yeast physiology and biotechnology. London: Wiley Editorial Offices, 1998. 350p.

WOOLFORD, M.K. The detrimental effects of air on silage. Journal Applied Bacteriology, v.68, p.101-116, 1990. 